\title{
Motivation And Entrepreneurs Training For Tinggi Raja Society Of Asahan Regency
}

\author{
Tengku Syarifah \\ Management Department \\ Faculty Of Economic \\ University Of Asahan \\ Medan, Indonesia
}

\author{
M. Umar Maya Putra \\ Management Department \\ Faculty Of Economic \\ University Of Al Azhar \\ Medan, Indonesia \\ *Corresponding Author: umar_yazli@yahoo.com
}

\begin{abstract}
This paper is a concept of management training in motivation and entrepreneurship in the Tinggi Raja Society of Asahan Regency. Through this program, it is expected that Tinggi Raja Society knows the importance of motivation and entrepreneurship in improving community empowerment. The method that will be used is experiential learning method and the concept of literature study about entrepreneurship. The delivery in the form of lectures, group discussions, games so that people can participate actively in this activity. In the training presented the material: Concept of Motivation and Concept of entrepreneurship. After the activities were conducted, it was found that the participants were quite responsive and enthusiastic in following the training materials, as evidenced by the many questions asked by the participants. However, because the participants' knowledge of the concept of motivation and entrepreneurship is still very low then they need further coaching in order to apply the two concepts.
\end{abstract}

Keywords: management, entrepreneurship, Tinggi Raja, Asahan

\section{INTRODUCTION}

If we discuss the flow of thinking from Micro Small and Medium Enterprises (SMEs), which at this time developed the concept of entrepreneurship to independence, then their natural attitudes can create jobs and reduce the sense of dependence on the private sector and the government, especially in terms of financial and will grow Courage and self-proactive mental victory / Out of The Box.

The government has launched the National Entrepreneurship Movement in this year. The intent and purpose of the National Entrepreneurs Movement 2013 awaken the spirit and motivation about entrepreneurship to the community, especially the younger generation. This is the time for us to work from the beginning to improve the mindset out of the box [1]. By thinking of creating new creations, all the usual things are amazing. Starting from ourselves, our spirit, of course, Asahan regency will rise to become a city that has a high creation power in creating business opportunities and support from all generations until the government is a close combination to realize the creativity of lifting the culture and bring tourists continuously.

As the development of SMEs in Asahan regency as entrepreneurs, the human will is against the tremendous obstacles due to the rise of the cultivated depending on intelligence to create a strong production, marketing and mental strategy and also self-serving businessman (self presentation). Good communication in presenting something, must have a concept based on customer based. Customer based (customer approach) must certainly look at the psychology willingness by consumers such as packaging, how to speak, product presentation techniques, to how to convince customers to buy as needed and keep using the product because it has a good quality and close proximity between sellers and customers .

On this occasion, increasing the synergy between SMEs in Tinggi Raja which leads from the beginning of private entrepreneur formation and the need for cooperation from related institutions such as Asahan Industry Office and Academician from Asahan University. Synergy between Governments and Academics will create a good cooperation to improve the common welfare that became the best foundation in the management of entrepreneurship in Asahan regency so that from the side of the comparison is made motivation and entrepreneurship training for 50 SMEs so that the business produced, will have the ability of competitiveness and competitive advantage.

The main issues to be studied are how much the development of motivation and entrepreneurship of the Asahan Society Case Study: Tinggi Raja Community and whether appropriate recommendations are used to improve the Development of the Asahan Community Entrepreneurship Case Study: Tinggi Raja.

Motivation to become entrepreneur comes from various sources. Usually people tend to become self owner and be own boss in the business area have high motivation to become 
entrepreneur. High motivation also relates to having high self esteem in individual aspects. This is because, high self esteem people tends to drives to take on the risk, the uncertainty and the independent structure of business ownership successfully [2].

Knowing the motivational factors that drive people into entrepreneurial activity is important as it can provide valuable information for government or any institution to devise proper program and methods to be used in boosting youth entrepreneur [3].

Motivation is a desire or need in exerting behavior or spirit in achieving a goal both personal and organizational goals. Desire or need can come from the individual self but can also come from the leader of an organization [4].

Another interesting consideration is that the mean age of the businesses studied was nine years. At that point in the life of the business, the challenges of the tumultuous start up period have passed and general management of the business and record keeping are important to the ongoing operation and growth of the business [5].

The modification of motives would probably produce an increase of chances for growth of their SMEs in the marketplace. This modification ought to be directed not in changing current motives, but to add motives concerned with sustainable development of enterprise in a long run [6].

The idea can be the result of discovering a new product, a new technique and a new know how, especially for engineers and technicians who invent new processes. To build an idea, is interesting to take place in the good networks and to see frequently the good actors [7].

The motivation of entrepreneurs is influenced by the external as well as internal environmental factors. Though there is no research study which reveals the extent to which the entrepreneurs are motivated by these two environments it is found that the entrepreneurial motivation is due to the influence of both the external and internal environmental factors [8].

By understanding the nature of entrepreneurial selfefficacy and mechanisms through which it affects entrepreneurial outcomes, we obtain insights into the effectiveness of business start-up processes and can thus provide practical implications on skill-building exercises for individuals [9].

Entrepreneurship is claimed as an important element to stimulate growth and development of most countries. It is also posited that female entrepreneurs took part and played a vital role in the economic development and helped to stabilize the economy particularly during the economic recession periods [10].
It aims to ascertain the students' interest in future business after graduation and motivational factors that lead them to favor business. Economic instability of the labor market and the threat of unemployment calls for continuous improvement of business education of potential entrepreneurs at universities for possible influence of their further career choices [11].

Findings from their studies show that motivation of entrepreneurs falls into four distinct categories: 1. extrinsic rewards, 2. independence/autonomy, 3.intrinsic rewards and 4.Family security. These four groups of factors determine the motivation level of entrepreneurs which in turn affects on their business success [12].

\section{METHOD AND MATERIAL}

The method that will be used is experiential learning method and the concept of literature study for 50 entrepreneurs at random with a description of 33 trading businesses and 17 oil palm plantations. The delivery in the form of lectures, group discussions, games so that people can participate actively in this activity. In the training presented the material: concept of Motivation and Concept of entrepreneurship. After the activities were conducted, it was found that the participants were quite responsive and enthusiastic in following the training materials, as evidenced by the many questions asked by the participants. Data source in this research is from the international journal, book, Central Bureau of Statistics transferred into focus group discussion with the participants.

\section{RESEARCH RESULTS AND DISCUSSIONS}

In the study of concept of Motivation and Concept of entrepreneurship which is the core of the entrepreneurship development material to realize the competitive culture for Tinggi Raja community conducted to 50 entrepreneurs at random with a description of 33 trading businesses and 17 oil palm plantations invited in the training with the concept of deepening are:

\section{A. Implementation of concept of motivation}

In [2] investigated that motivation to become entrepreneur comes from various sources. Usually people tends to become self owner and be own boss in the business area have high motivation to become entrepreneur. From this, it is a forerunner that can be developed for Tinggi Raja who is engaged in trading businesses and oil palm plantations. Beginning with trying to form a motivation will need to have access to information from within and abroad on the development of the business that is focused.

Complete information is an effective means of building entrepreneurial spirit in Tinggi Raja. As the investigation [3] that knowing the motivational factors that drive people into entrepreneurial activity is important as it can provide valuable information for government or any institution to devise proper program. Government programs and education can direct 
business development to be more focused and certainly required to know the business objectives both in short and long term.

With the right purpose of a business that is occupied will improve the spirit of motivation that is the desire or need in directing the behavior or spirit in achieving a goal both personal and organizational goals. By knowing the right business objectives of the motivation that has been run, will certainly get a picture of business development and the way the business in the community as the research [4], [6] and [7].

By the research [5] told that the age of a business is not predictable in particular its development. Another interesting consideration is that the mean age of the studied was nine years. At that point in the life of the business, the challenges of the tumultuous start up period have passed and general management of the business. [12] said that there are some things that need to be thought of business development can achieve entrepreneurial motivation that can be expressed with four distinct categories of motivation: 1. extrinsic rewards, 2. independence / autonomy, 3. intrinsic rewards and 4.Family security. 4 parts of this can be developed a motivation to the appropriate business direction and could make the business more clearly in line with the mechanism to realize the desire empirically.

\section{B. Implementation of concept of entrepreneurs}

From the development of motivation incorporated in the training participants in Tinggi Raja, based on the classification included in the category of SMEs. The development of SMEs that are supported by good knowledge will benefit the economy of a region. It can contribute to Asahan Regency from the economic sector, if SMEs sector is developed properly. The synergy of the educational world that gives the idea of discovering a new product, a new technique and a new know how, especially for engineers and technicians who invent new processes. There is the correlation with [8] research that technical parties are directed in favor of creating operational mechanization based on the potential of SMEs and environmental potential.

The motivation of entrepreneurs is influenced by the external as well as internal environmental factors. Internal factor that often happens is owned by science with external factor that is environmental condition. The environment that provides the potential of the agricultural sector in Tinggi Raja needs to be developed to better understand the direction and achievement mentioned. By understanding the nature of entrepreneurial self-efficacy and mechanisms through which it affects entrepreneurial outcomes that is similar to the research [8] and [9].

Entrepreneurship is claimed as an important element to stimulate growth and development of most countries so if the basic capital is improved continuously, In the future business after graduation and motivational factors that lead them to favor business. Tinggi Raja's People should be able to do something innovation with pride in being an entrepreneur and if anyone completes their education, it is expected to develop motivation to increase entrepreneurship to the success of economic development as the research [9], [10] and [11].

\section{Discussion}

From all the deepening of the material transferred to Tinggi Raja community, there are several things that are questioned about motivation entrepreneurship. This is related to the expectation toward invention and innovation. Some hope that enlightenment needs to be given:

- Making a herbal cafe that cures mild and chronic diseases with materials from plants in the Tinggi Raja. R \& D has demonstrated success and needs a reinforcement concept of a business plan that has been done by a successful businessman before. The presenters recall the foundation of social entrepreneur and business ethics to join the community associated with this venture. Approaches with health-related offices, food supervision and drugs are felt to be necessary by joining the business community. The business community is a way to create invention and innovation due to frequent meetings and conduct coaching related to academic and governmental patterns. If they want to join other communities, it will create a business result that will improve the results of a growing business continuously. The recommendation made as the research [2], [3],[8],[9] and [10]

- Need of academic assistance with the motivation to manage waste becomes more productive, especially to be environmentally friendly. Internally developed motivation is expected to manifest itself with the concept of operational mechanization and the training that supports both government and academic support. With the training given to entrepreneurs in Tinggi Raja, three are some graduation made to the favor business and motivation similar to the research [11] and [12].

There are several achievements from this training such as :

- Increasing the mindset that through the concept of Motivation entrepreneurship can improve the responsive and enthusiastic conducted by extension methods. After counseling, there are 50 participants who have increased understanding of entrepreneurship to create independence. As the research [4].

- Exercise business activity in presenting the product in a structured manner and the technique presents a good sale with the empirical concept though game. In this Entrepreneurship training technically sales creates 50 participants who are able to sell in a structured manner and the technique of presenting the product with the concept of business plan as the research [7]. 
The end of the activity, the community and some community leaders and government actors make a joint commitment to an achievement of the results of activities tied up with Memorandum Of Understanding (MOU) which became a bond in terms of business development located in Tinggi Raja. The pattern of independence activities that have been implemented in the short term from the Tinggi Raja community, needed a close development to create invention and innovation. By developing research \& development patterns need to be evaluated and joined by businesspeople to communities that create a pattern of independence and think about business progress and change local landscape continuously. The close partnership of government, society and academia is the solutions that can be done to achieve a higher business outcome and business people are directed to achieve higher competition that touches the international market aspect in the long run as the research [5] and [6].

\section{CONCLUSIONS AND RECOMMENDATIONS}

\section{A. Conclusions}

From this entrepreneurship training, there are several conclusions:

1.50 random entrepreneurs with descriptions of 33 trading businesses and 17 oil palm plantations invited in training with the concept of motivational and entrepreneurship.

2. From the Implementation of concept of motivation in entrepreneurship because of willingness tobe come self owner and be own boss in the business area have high motivation to become entrepreneur, Knowing the motivational factors that drive people into entrepreneurial activity is important as it can provide valuable information for government or any institution to devise proper program, desire or need in directing behavior or spirit in achieving a goal both personal and organizational goals, four distinct categories of motivation: 1.extrinsic rewards, 2. independence/autonomy, 3. intrinsic rewards and 4. family security.

3. From the implementation of concept of entrepreneurs such as the modification of motives would probably produce an increase of chances for growth of their SMEs in the marketplace, The synergy of the educational world that gives the idea of discovering a new product, a new technique and a new know how, especially for engineers and technicians who invent new processes. By understanding the nature of entrepreneurial self-efficacy and mechanisms through which it affects entrepreneurial outcomes, we obtain insights into the effectiveness of business start-up processes, Entrepreneurship is claimed as an important element to stimulate growth and development of most countries.

4. Some hopes that enlightenment needs to be given such as: creating herbal cafes that cure mild and chronic diseases with materials from plants in Tinggi Raja and Need of academic assistance with the motivation to manage waste becomes more productive, especially to be environmentally friendly. Internally, It developed motivation is expected to manifest itself with the concept of operational mechanization and the training that supports both government and academic support.With the training given to entrepreneurs in Tinggi Raja.

5. From this training activity, there are some achievements that are achieved such as increasing the mindset that through the concept of motivation entrepreneurship can improve the responsive and enthusiastic conducted by extension methods. After counseling, there are 50 participants who have increased understanding of entrepreneurship to create independence and exercise business activity in presenting the product in a structured manner and the technique presents a good sale with the empirical concept though game. In this Entrepreneurship training technically sales creates 50 participants who are able to sell in a structured manner and the technique of presenting the product with the concept of business plan.

\section{B. Recommendations}

1. From the activity, among community, some leaders and government actors commit together to do an achievement of the results of activities tied up with MOU in order to continue to be evaluated.

2. The pattern of independence activities that have been implemented in the short term from the Tinggi Raja community, needed a dynamic development to create invention and innovation and synergy with the long term.

3. The need for support from the expectations of the community from all walks of life to achieve a higher competition that touches the international market aspect in the long run and need further coaching in order to apply the two concepts.

\section{REFERENCES}

[1] Http://www.infoevent.co.id. http://www.infoevent.co.id. Retrieved 0130 , 2016, from http://www.infoevent.co.id. 2013.

[2] Munir, Zarina Abdul., Idrus, Syukuriah., Shukur, Shamsul Azren Mohd., Ithnin, Rahimah and Mohamad, Siti Sarah. The Effectiveness Of Entrepreneurial Motivational Training Programme Among University Students. International Journal Of Social Science And Humanity, Vol. 5, 2015, pp.87-490.

[3] Sihombing, Rodeta., Rachmawati, Evy CH. Understanding Motivational Factors Affecting Entreprenurial Decision : A Comparison Between Bandung Student Entrepreneurs And Student Non Entrepreneurs (Case Study For Bandung Institute Of Technology Student). Journal Of Business And Management Vol. 4, 2015, pp.615-622.

[4] Dewi, Erwita., Yacob, Syahmardi., Octavia, Ade., Jamal, H. M. S and Setiawati, Rike. Pelatihan Motivasi Dan Kewirausahaan Bagi Tim Penggerak Pkk Kelurahan Rawasari Kecamatan Kota Baru Kota Jambi. Jurnal Pengabdian Pada Masyarakat No. 52, ISSN: 1410-0770, 2012, pp.80-88. 
[5] Zimmerman, Monica A and Chu, Hung Manh. Motivation, Success, And Problems Of Entrepreneurs In Venezuela. Journal Of Management Policy And Practice Vol. 14, 2013, pp.76-90.

[6] Stefanovic, Ivan., Prokic, Sloboda and Rankovic, Ljubodrag. Motivational And Success Factors Of Entrepreneurs:The Evidence From A Developing Country. Zb. Rad. Ekon. Fak. Rij. Vol. 28, 2010, pp.251269.

[7] Farouk, Amari., Ikram, Abbes. The Influence Of Individual Factors On The Entrepreneurial Intention. International Journal Of Managing Value And Supply Chains (Ijmvsc) Vol. 5, 2014, pp. 47-57.

[8] Mukherjee, Kaushal. The Psychology Of The Successful Entrepreneur. International Journal Of Advanced Engineering And Management Vol 1 No 1, 2016, pp.25-32.

[9] Nyang'au, Samson Paul., Mukulu, Elegwa and Mung'atu, Joseph. The Influence Of Entrepreneur's Motivation On Growth Of Micro And Small Enterprises In Thika Town, Kenya. International Journal Of Business, Humanities And Technology Vol. 4, 2014, pp.123-128.

[10] Mustapha, Mazlina., Subramaniam, Punitha A/P. Challenges And Success Factors Of Female Entrepreneurs: Evidence From A Developing Country. International Review Of Management And Marketing ISSN: 2146-4405, 2016, pp.224-231.

[11] Hrehová, Daniela. Motivation To Become An Entrepreneur. Grant Journal ISSN 1805-062x, 1805-0638 (Online), 2013, pp.42-46.

[12] Drnovšek, Mateja., Wincent, Joakim and Cardon, Melissa S. Entrepreneurial Self-Efficacy And Business Start-Up: Developing A Multi-Dimensional Definition. International Journal Of International Journal Of Research Vol. 16, 2010, pp.329-348. 